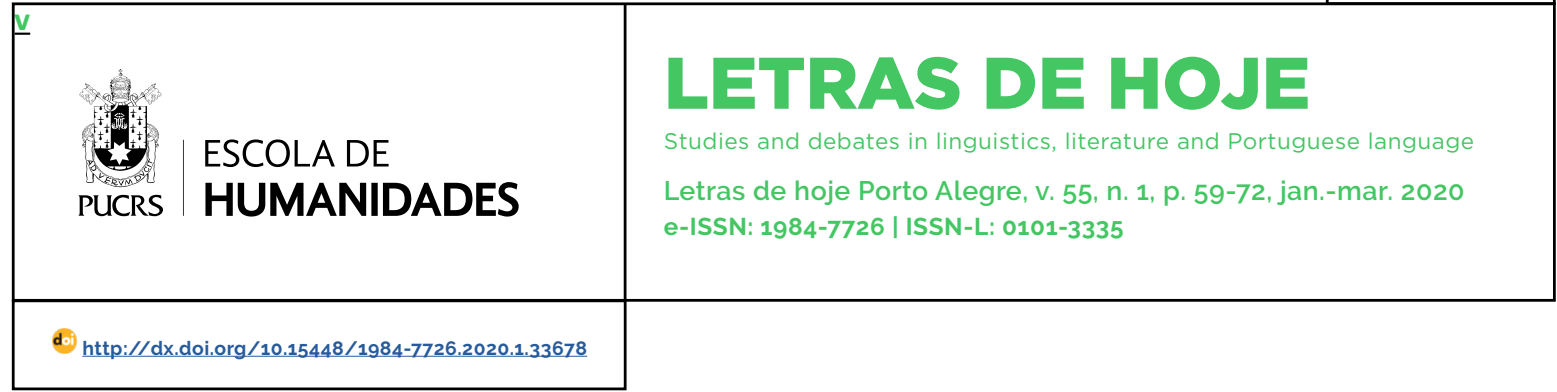

\title{
O modo como expressão do ponto de vista em Dom Casmurro, o romance, e Capitu, a microssérie
}

The mode as expression of the point of view in Dom Casmurro, the novel, and Capitu, the micro series

El modo como expresión del punto de vista en Don Casmurro, la novela, y en Capitu, la microserie

\section{Alexandre de Assis Monteiro ${ }^{1}$ \\ orcid.org/0000-0002-1670-5668 moinhosdevento1@hotmail.com}

Luiz Antonio Mousinho² orcid.org/0000-0002-7730-3195 $\underline{\text { Imousinho@yahoo.com.br }}$

Recebido em: 25 mar. 2019. Aprovado em: 19 dez. 2019. Publicado em: 14 abr. 2020.

\section{(c) (i)}

Artigo está licenciado sob forma de uma licença Creative Commons Atribuição 4.0 Internacional.
Resumo: As obras Dom Casmurro, o romance, e Capitu, a microssérie possuem um modo de trânsito entre elas, operacionalizado recentemente (2008) por Luis Fernando Carvalho, que revela a adaptação do discurso verbal para o verbo visual, sem desconsiderar o fato de que todo o fornecimento de informação narrativa provém de uma única fonte: Dom Casmurro, o personagem narrador Essa adaptação nos instiga a adentrar os meandros deste processo a fim de compreender os diferentes pontos de vista, a ilusão de verdade, as autorias narrativas propostas inicialmente pelo autor-narrador da primeira obra e em seguida, pelo adaptador-focalizador da segunda. A tese eixo que propomos é a de que a fala ostensiva do narrador do romance não foi interrompida no fluxo narrativo das imagens, a ponto de fragmentar ou comprometer os seus significados, ao contrário, preserva-os e os viola ao mesmo tempo, construindo uma nova obra e ressaltando a identidade da "outra" na qual se ampara, sem que sejam as mesmas. Para a verificação e percepção do modo dessa transição, fundamentamo-nos nas categorias narrativas atinentes a narradores e focalizadores, a partir de suportes teóricos, conceituais e literários de vasta bibliografia anexa.

Palavras-chaves: Dom Casmurro. Capitu. Narrativa. Microssérie. Modo. Focalização.

Abstract: The works Dom Casmurro, the novel, and Capitu, the micro series have a mode of transit between them, recently operationalized (2008) by Luis Fernando Carvalho, which reveals the adaptation of the verbal discourse to the visual verb, without disregarding the fact that the whole supply of narrative information comes from a single source: Dom Casmurro, the narrator character. This adaptation instigates us to enter the intricacies of this process in order to understand the different points of view, the illusion of truth, the narrative authors proposed initially by the narrator of the first work and then by the focal-adapter of the second. The axis thesis we propose is that the ostensible speech of the narrator of the novel was not interrupted in the narrative flow of the images, to the point of fragmenting or compromising their meanings, on the contrary, it preserves them and violates them at the same time, constructing a new work and emphasizing the identity of the "other" in which it is protected, without being the same. For the verification and perception of the mode of this transition, we are based on the narrative categories related to narrators and focusers, from theoretical, conceptual and literary supports of vast bibliography.

Keywords: Dom Casmurro.Capitu.Narrative.Microseries.Mode.Focusing.

Resumen: Las obras Don Casmurro, la novela, y Capitu, la microserie, poseen un modo de tránsito entre ellas, recientemente (2008) operacionalizado por Luís Fernando Carvalho, qui revela la adaptación del discurso verbal hacia el verbo visual, sin desconsiderar el hecho de que todo el fornecimiento de información narrativa proviene de una sola fuente: Don Casmurro, el personaje narrador. Esa adaptación nos instiga a investigar los meandros de dicho proceso con la finalidad de comprender los distintos puntos de vista, la ilusión de verdad, las autorías narrativas propuestas inicialmente por el autor-narrador de la primera obra y, en 
secuencia, por el adaptador-enfocador de la segunda. La tesis central qui proponemos es aquella según la cual el discurso ostensible del narrador de la novela no fue interrumpido por el flujo narrativo de las imágenes, rompiendo y comprometiendo sus significados. Muy al contrario, los preserva y los viola al mismo tiempo, construyendo una nueva obra y poniendo de relieve la identidad de la "otra" en la cual se sostiene, sin que sean las mismas. Para la verificación y percepción del modo de esa transición, fundamentémonos en las categorias narrativas relacionadas a autores y enfocadores, partiendo de soportes teóricos, conceptuales y literarios de la amplia bibliografía anexa.

Palabras-clave: Don Casmurro. Capitu. Narrativa. Microserie. Modo. Enfocación.

Gérard Genette define uma importante categoria narratológica, partindo de um conceito/ aplicação gramatical, a que chama de modo. Como ele entende, modo é o nome dado às diversas formas do verbo para exprimir diferentes pontos de vista a partir dos quais se considera a existência ou a ação. Para efeito de elucidação, embora o objeto deste artigo tenha outras categorias narratológicas como periféricas, não podemos deixar de aludir ao conceito de focalização, a partir da mesma obra de Genette, fundamental para a integração e compreensão do que aqui propomos

O autor faz nítida separação entre narradores e focalizadores, tomando o conceito de focalização (ou foco narrativo ou ainda ponto de vista) para se referir à representação da informação que se encontra ao alcance de um determinado campo de consciência, seja do narrador, seja de um personagem. Em outras palavras, é o olhar do personagem ou do narrador, como ele percebe e filtra a história para além do sentido da visão. Assim, o ponto de vista, focalização ou foco narrativo, responde à pergunta sobre qual personagem orienta a perspectiva narrativa ou quem é o focalizador. Numa equação diremos mais simples: o narrador é quem narra; o focalizador é quem vê. mas o narrador pode ser também detentor da focalização, sendo então narrador e focalizador, em tal ou qual segmento narrativo.

No caso do cinema, um filme pode ter um segmento em câmera subjetiva (simulação do que o personagem vê), mas o "olhar", a percepção que orienta a perspectiva narrativa, o ponto de vista, não ser a do personagem. A focalização³ , ou foco narrativo, tem a ver com restrição de foco, quando a narrativa tem ponto de vista limitado (a um ou mais personagens ou ao narrador com ponto de vista limitado). Quando a narrativa é onisciente - quando o narrador vê tudo - então não há ponto de vista limitado (focalização zero ou narrativa não focalizada; visão por trás, narrador > que personagem). Mas pode haver infrações do código e, numa narrativa onisciente, certos dados podem ser escondidos do espectador para serem revelados depois em paralipse.

Assim, o modo narrativo possibilita - ou tipifica - a forma como a história é contada, segundo um ou outro ponto de vista e, cada um, fornece a informação narrativa à sua maneira, com mais ou menos pormenores, mais ou menos diretamente e deste ou daquele lugar, estabelecendo um grau de distância e uma perspectiva em relação àquilo que se conta (GENETTE, 1979, p. 160).

Para nos suster na questão, acorremos ao que Maria Lúcia Dal Farra descreve como ponto de vista (1978), em sua prolífera ideia do conceito:

Na verdade, aquilo que se tem considerado ser o ponto de vista do narrador $e$ que, segundo se afirma, filtra o mundo e dá forma e nome às coisas, nada mais é que uma postura visual regulada por uma ogiva maior: aquela que enxerga no defeito ou na amplitude de visão conferida ao narrador a certeza do sucesso dos valores que quer manipular. Assim, a ótica do universo nascerá do confronto entre a luz e a sombra, entre o ponto de vista do narrador - que pode percorrer toda a hierarquia das visões desde a onisciência até o foco mais restrito - e os pontos de cegueira do narrador (DAL FARRA, 1978, p. 23, 24).

Quando se considera o ponto de vista do narrador é necessário levar em conta, ao mesmo tempo, o que ele vê e o que ele não vê: o que ele foi levado a não enxergar. As supostas omissões

\footnotetext{
3 A focalização pode ser definida como a representação da informação diegética que se encontra ao alcance de um determinado campo de consciência, quer seja o de uma personagem da história quer o do narrador heterodiegético [que não participa da história] consequentemente, além de condicionar a quantidade de informação veiculada (eventos, personagens, espaços, etc.), atinge a sua qualidade, por traduzir uma certa posição afetiva, ideológica, moral e ética em relação a essa informação. REIS, Carlos; LOPES, Ana Cristina M. Dicionário de Teoria da Narrativa, p 119, 122. São Paulo: Editora Ática, 1988.
} 
poderão desencadear novas arregimentações para a história, ou seja, podem suplantar óticas anteriores e postular novas visões e intervenções sobre a mesma história.

A contribuição da categoria modo interessa sobremaneira à análise dos textos que compõem o corpus deste artigo: Dom Casmurro, romance de Machado de Assis publicado pela primeira vez em 1899, e Capitu, microssérie de Luís Fernando Carvalho lançada em 2008. A grande polêmica - e trunfo - das duas narrativas envolve o fato de que todo o fornecimento de informação provém de uma única fonte, Dom Casmurro, o personagem narrador. Pelo menos a partir da crítica feita pela teórica americana Helen Caldwell (2002) em seu $O$ Otelo brasileiro de Machado de Assis, em que põe em cheque a veracidade da informação narrativa do romance, adverte para o fato de que a Capitu não é dada voz. Se isso tivesse acontecido, a compreensão do texto muito provavelmente seria outra.

Dessa maneira, constatamos o quanto a perspectiva (local de onde se tem o ponto de vista) se relaciona e influi sobre a distância (teor de informação liberada pelo narrador). O ludibrio, através das peripécias narrativas, como sugere Gledson (1991), operado sobre o leitor, tem tudo a ver com o fato de que a informação é fornecida exclusivamente por Dom Casmurro, o que the assegura o poder de elisão, suspensão, prolepses etc. como the convém para convencer seu leitor.

A partir da tipologia proposta em 1967 por Friedman compreendemos que Dom Casmurro pode se encaixar como um narrador-protagonista. Anos mais tarde, em O discurso da narrativa, obra de 1972, Genette lançará mão das formulações de Friedman, já assentadas e reconhecidas, sobre "perspectiva e distância", e que fornece definição preciosa sobre esse tipo de narrador,

[...] conta a história na primeira pessoa, alguns outros canais de informação são eliminados e mais alguns pontos de vantagem, perdidos. Devido a seu papel subordinado na própria histó- ria, o narrador-testemunha tem uma mobilidade muito maior e, por consequência, uma amplitude e variedade de fontes de informação bem maiores do que o próprio protagonista, que se encontra centralmente envolvido na ação. O narrador protagonista, portanto, encontra-se quase que inteiramente limitado a seus próprios pensamentos, sentimentos e percepções. [...] o ângulo de visão é aquele do centro fixo. [...] a distância pode ser longa ou curta, ou ambas (FRIEDMAN, 2002, p. 176, 177).

A conveniência do modo de narração (protagonista) de Dom Casmurro, além da limitação de sua visão em relação ao narradortestemunha, também envolve a questão da mimese ${ }^{4}$, pois, além de contar a história modalidade nomeada narrativa pura -, ele a mostra - utilizando segmentos dialogados. Ou seja, não só rememora, mas traz à vida novamente os personagens, seus espaços e suas ações através do discurso direto, "invocando, a seu tempo, ora o cuidado em contar as coisas tais como foram 'vividas' no momento, ora tais como são ulteriormente rememoradas" (GENETTE, 1979 , p. 155). Acerca disso, Lubbock salienta que:

\begin{abstract}
A "arte da ficção" não tem início até que o romancista pense sua história como algo a ser mostrado, a ser tão exposta que se conte por si mesma lem vez de ser contada pelo autorl... ela deve parecer verdadeira, e é tudo. Ela não se faz parecer verdadeira por simples afirmação (LUBBOCK, 1954, p. 112).
\end{abstract}

Lubbock exibe uma percepção sobre os modelos de discurso narrativo que superestima o recurso do discurso direto em detrimento do uso do discurso indireto. Em oposição a esse pensamento, podemos citar, em caráter ilustrativo, o caso do filme O homem que copiava (FURTADO, 2003), em que a presença tenaz da voz do narrador, apesar de quebrar (BERNARDO, 2010, p. 166), não compromete a eficácia do contrato ficcional estabelecido entre a narrativa e o espectador. Em Capitu e em Dom Casmurro, ao contrário de como

\footnotetext{
4 Genette (1979, p. 162) afirma que a única mimesis possivel em narrativa é a ilusão de mimesis, já que a realidade (mesmo a diegética) passada é intangivel e a linguagem apenas supostamente consegue recuperá-la. Preferi a praticidade do termo mimesis em todo o estudo, mas se entenda ilusão de mimesis. Utilizo o termo em sentido estrito, como pensava Platão (apud LEITE, 2002, p. 7): alicerçado na ideia de imitação, cena, cópia infiel e simulacro do real e da verdade, em detrimento do sentido lato, em que o termo, independentemente de o discurso mostrar ou contar, se liga a própria noção de representação poética.
} 
Lubbock concebe a narração, o discurso contado acaba por reforçar o que é mostrado.

Friedman, por sua vez, finda por ratificar o equívoco de Lubbock, tomando outro caminho

Se a verdade artística é uma questão de compelir a expressão, de criar a ilusão da realidade, então um autor que fale em sua própria pessoa sobre as vidas e fortunas de outros estará colocando um obstáculo a mais entre sua ilusão e o leitor, em virtude de sua própria presença (FRIEDMAN, 2002, p. 169).

Parece haver, no argumento de Friedman, uma confusão entre narrador e autor, ou ainda entre autor e autor implicado 5 , que seria uma instância com voz diegética que não pode ser atribuída a personagens nem ao narrador. Não ignoremos que ele propõe como solução para que o autor se esquive de comprometer o sentido de ilusão da narrativa, com sua intromissão, escrever em terceira pessoa, para que a história passe a ser algo de responsabilidade de um personagem. ${ }^{6}$

O rompimento da ilusão de realidade, ademais, não se dá de forma tão simples. Alguns autores, inclusive, ironizam ou dão sentido jocoso à relação entre diegese e realidade.

Woody Allen, em Noivo neurótico, noiva nervosa (ALLEN, 1977), supera o tabu que cerca e distancia o personagem do narrador-câmera, aquele que, no texto audiovisual, vê, mostra, ouve os acontecimentos e os transmite ao espectador. Na cena do filme se passa numa fila de cinema. Ao perder a paciência com um pernóstico e verborrágico intelectual que esbanja conhecimento sobre teorias do filósofo Marshall McLuhan perto de si, o personagem vivido por Woody Allen, Alvy Singer, olha para a câmera e estabelece contato direto com seu narratário: "O que fazer quando se fica preso numa fila com um cara desses atrás?". Alvy, então, puxa McLuhan de outro ponto "da cena" e o faz ratificar o equivoco do rapaz, ao desconstruir os argumentos do pedante espectador, volta a olhar para a câmera e diz: "Se a vida fosse assim!".

Em Baixio das bestas, filme de Cláudio Assis (2007), Everardo, personagem de Matheus Nachtergaele, numa cena que, curiosamente, também se passa dentro do cinema, que é o lugar usado pelos personagens para a prática de contravenções, olha para a câmera e pergunta: "Sabe o que é que é o melhor do cinema? É que no cinema tu pode fazer o que tu quer".

Esse recurso, do olho no olho, para Anna Maria Balogh (BALOGH, 2004, p. 166,167), constitui uma estrutura conversacional rara na TV, sobretudo em programas ficcionais. Mas, talvez, na verdade, esteja até vulgarizado na teleficção. Ele é muito usual nas séries e programas humoristicos.

Em Os normais (TV Globo) ou nos episódios dos programas já encenados pelo humorista Renato Aragão, como A turma do Didi (TV Globo), os personagens estão constantemente estabelecendo esse contato com o espectador. Mesmo na TV, o recurso parece só combinar com esse tipo de programa. No cinema, porém, é incomum. Aparece em obras sem caráter cômico e ainda constitui uma estrutura de agressão. ${ }^{7}$

A explicação para os efeitos semânticos e psicológicos do recurso do "olho no olho" no cinema e na TV pode estar em Marcel Martin (2003), em suas reflexões sobre o processo de liberação da câmera.

Para o autor, a comédia cinematográfica, em principio, utilizou o recurso com o intuito de fazer

\footnotetext{
5 Autor implicado (ou autor implícito) é, talvez, a categoria narrativa e o ser da narração mais caro às contribuições de Maria Lúcia Dal Farra (1978) em O narrador ensimesmado. Ele, segundo Dal Farra, parece coordenar, gerir e fazer existir toda espécie de narrador e de narração. Seria "uma máscara do autor implícito". Para atestá-lo basta reparar na recorrência a essa categoria em suas citações e na adjetivação que ela usa para se referir a este ser (diegético?): "criador mítico do universo" e possuidor da "mente detentora dos poderes romanescos" (DAL FARRA, 1978, p. 22, 23, 42). O espaço que dispomos aqui impedirá que nos prolonguemos na discussão do conceito e da ação do autor implicado por considerá-la demasiada "problemática e complexa", como afirmam Carlos Reis e Ana Cristina M. Lopes em seu dicionário de narratologia (REIS, Carlos; LOPES, Ana Cristina M., 1988). Ademais pôr de lado essa categoria dos estudos narrativos não deverá comprometer a coesão deste trabalho, que é centrado na teorização do narrador e da narração, e menos no autor.

6 A focalização pode ser definida como a representação da informação diegética que se encontra ao alcance de um determinado campo de consciência, quer seja o de uma personagem da história quer o do narrador heterodiegético [que não participa da história] consequentemente, a focalização, além de condicionar a quantidade de informação veiculada (eventos, personagens, espaços, etc.) atinge a sua qualidade, por traduzir uma certa posição afetiva, ideológica, moral e ética em relação a essa informação. REIS, Carlos: LOPES, Ana Cristina M. Dicionário de Teoria da Narrativa, p. 119, 122. São Paulo: Editora Ática, 1988.

7 Termo cunhado por Freud, em O estranho (1919), para se referir ao incômodo por que passa o sujeito ante algo a que seus olhos não estão condicionados, causando estranheza, em oposição ao que é "familiar" (FREUD, 1986, p. 241).
} 
do espectador uma testemunha do paradoxo de personagens histriões, bobos e burlescos, pronunciando sentenças espirituosas. E no caso do filme não cômico, o cinema fez o personagem se dirigir diretamente ao espectador para que ele se sentisse mais atingido pela situação, potencializando o efeito dramático sobre o que vê. Já em Capitu, o olho no olho é tributário das lições da comédia e do drama, pois, ao mesmo tempo em que torna o espectador uma testemunha do paradoxo de um burlesco narrador contando sua trágica história de vida, o close potencializa o efeito dramático da dor que o perpassa.

Retomando a questão que envolve o dilema entre contar ou mostrar a história, Friedman (2002, p.171), coloca a questão "quem fala ao leitor?" como fundamental para a interpretação da narração e, paradoxalmente, considera a viabilidade, em alguns casos, da resposta: ostensivamente ninguém. Isso fica mais evidente na narrativa audiovisual, por não podermos ver quem fala. Ao assistir somos tentados a atestar a verdade genetteana: na mimese prevalece em grau máximo a informação em detrimento do informador. Não é tão simples se pensarmos que a informação narrativa é um discurso articulado por um emissor que é o próprio narrador-informador. ${ }^{8}$

Em termos generalizantes, a narração simples ou em panorama ou o discurso indireto ou o contar a história ou a modalidade de narrativa pura colocaria o discurso em um estado de maior distanciamento entre a enunciação e o enunciado, ou manteria a informação como algo mais distante do acontecimento. Maria Lúcia Dal Farra (1978, p. 30), conceitua panorama como a posição do narrador exercendo uma visão generalizada ou quando o narrador está interessado num único e particular momento em oposição à imitação ou à cena ou ao discurso direto/relatado/reportado ou mimético, (tal qual se vê também em FRIEDMAN, 2002, p. 169),ou como segmentos dialogados.

Conforme Genette (1979, p. 173), nesta forma, "o narrador dilui-se e a personagem the substitui". Em suma, deve-se entender cena como "representação", com discursos diretos; e panorama, como "narração", com discurso indireto de um narrador (TODOROV, 1971, p.242).

Para Dal Farra (1978) a apresentação do discurso pode ser tratada de forma dramática - através de diálogos, fazendo com que a mente do narrador desapareça e a história se conte por si mesma ou ainda pode ser tratada de forma pictórica - que compreende a existência de um narrador que usa sua própria linguagem e seus próprios padrões de apreciação, "a fim de reproduzir alguma realidade que está em sua mente - e nesse caso a mente se transforma numa pintura" (DAL FARRA, 1978, p. 39 - 31). Essa forma nos interessa e nos ajuda a compreender um pouco mais da sinuosa narração de Dom Casmurro e Capitu, que, nesse caso, seria fortemente pictórica, pois os padrões de apreciação de Dom Casmurro em momento algum são postergados.

A zona limitrofe entre personagem e narrador ou, para ser menos generalizante agora, entre a autoria dos discursos, pode não ser tão demarcável, todavia. Uma divisão - para usar ainda um termo do campo semântico de limite-muito evidente é suspeita, a menos que incorramos no equívoco, como alertou João Batista de Brito em outro contexto, de esquecermos que o discurso, do tipo que for, com suas escolhas vocabulares e combinações sintáticas, sempre traz a marca do enunciador, e que tudo o que se vê na história resulta de uma construção (BRITO, 2006, p. 162) no mínimo do narrador, mas também, potencialmente, do próprio personagem.

Ligia Chiappini Leite (2008) ao refletir historicamente sobre a polêmica em torno do foco narrativo, afirma que

As HISTÓRIAS narradas pelos homens foram-se complicando, e o NARRADOR foi mesmo progressivamente se ocultando, ou atrás de outros narradores, ou atrás dos fatos narrados, que parecem cada vez mais, com o desenvolvimento do romance, narrarem-se a si próprios (LEITE, 2002, p. 5).

\footnotetext{
8 A esse respeito, a professora Sandra Luna, do Programa de Pós-Graduação em Letras da UFPB, adverte que, na arte icônica, para além do narrador protagonista, há a instância narrativa extradiegética, mas há muito de "ostentação", o que problematiza significativamente esse "poder" do narrador.
} 
Na narrativa audiovisual não é diferente, e geralmente o "problema" da ilusão de invisibilidade do narrador se torna ainda mais agudo. Brito (2006, p. 162) defende que, em oposição ao discurso literário, a instantaneidade do movimento e a objetividade da imagem, no discurso cinematográfico (ou em outros discursos de gêneros audiovisuais), intensificam a ideia ilusória de anulação do narrador e diluição de sua voz.

Entretanto, se no caso do livro Dom Casmurro, dificilmente o narrador se deixa "esquecer", devido ao seu já comentado modo excêntrico de narrar, no caso da microssérie isso é ainda mais difícil, já que, além do discurso, a imagem (visual) de Dom Casmurro é explorada à exaustão. Seria dificil responder que, em Capitu, quem fala é "ostensivamente ninguém". Aqui pontuamos que, quando o Dom Casmurro da microssérie é visto como um ser contrário à graça e a beleza, sua "imagem" ao invés de se impregnar na visão do espectador, pode ser apagada, distanciada.

Dispomos de um exemplo excepcional encontrado em Capitu. A adaptação de todo o capítulo da obra, CXXII - O enterro, é feito inteiramente sem falas de personagem ou narrador. Isso nos permite perceber as perdas e ganhos da troca de um enunciado exclusivamente verbal para um audiovisual.

A tendência à ilusão de anulação do narrador e diluição de sua voz, por um lado, é extrema, em que pese o subjetivo e denso teor informativo e criativo disponibilizado pela imagem e pelo som. Por outro lado, o déficit de informações pontuais como horários, tempo, estados de espírito ou interesses pessoais de cada personagem no evento é patente. Comparemo-los:

Saí de lá cerca de onze horas. Capitu e prima Justina esperavam-me, uma com o parecer abatido e estúpido, outra enfastiada apenas.

- Vão fazer companhia à pobre Sanchinha, eu vou cuidar do enterro. [...] José Dias ouviu também falar dos negócios do finado, divergindo alguns na avaliação dos bens [...] Tinha-as escrito [as palavras do discurso] com receio de que a emoção me impedisse de improvisar. No tilburi em que andei uma ou duas horas, não fizera mais que recordar o tempo do seminário, as relações de Escobar, as nossas simpatias, a nossa amizade, começada, continuada e nunca interrompida [...] (ASSIS, 2000, p. 160).

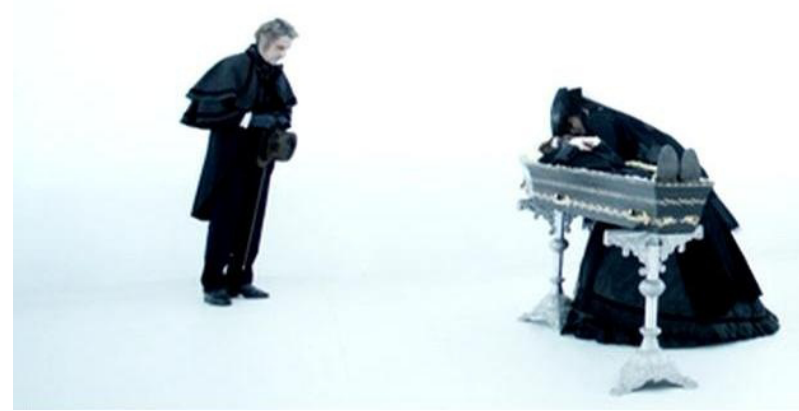

Imagem 1 - Panorama do velório de Escobar (CARVALHO, 2009). 


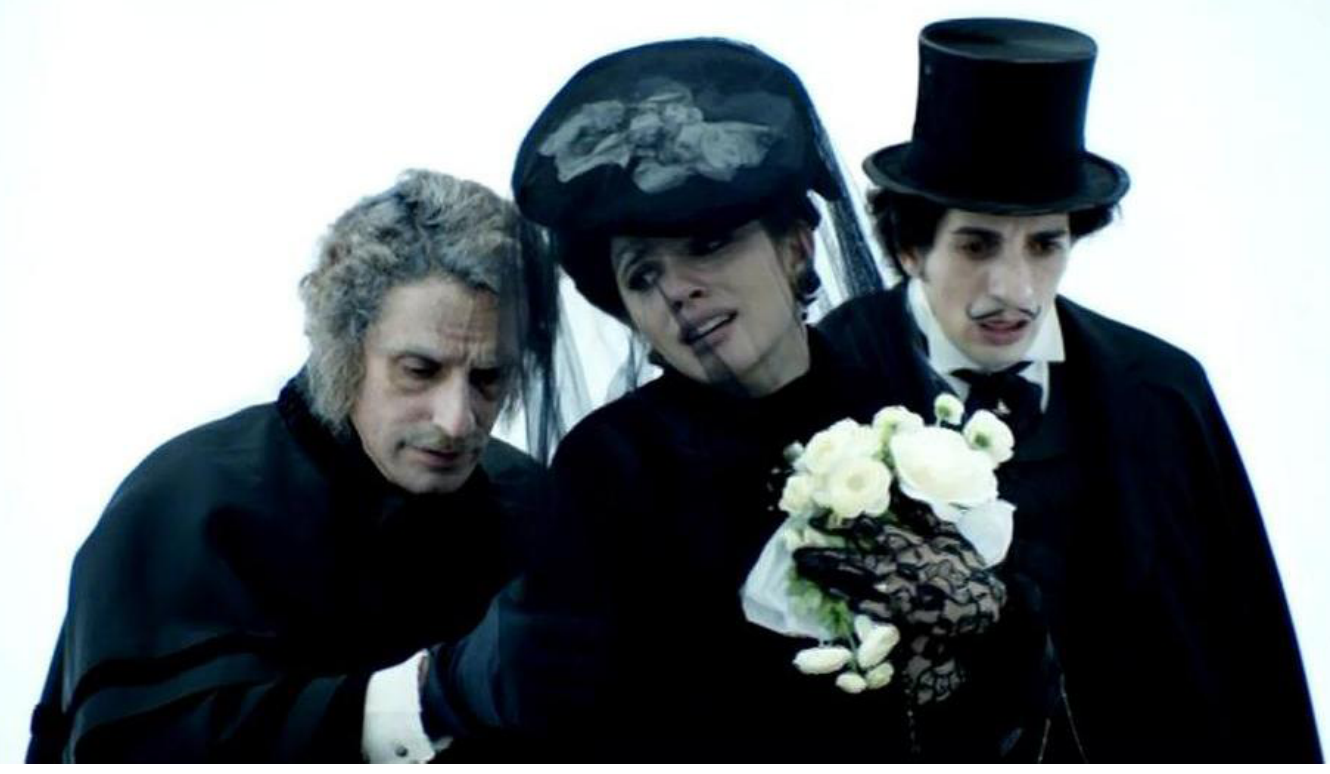

Imagem 2 - José Dias, Sancha e Bento durante velório de Escobar (CARVALHO, 2009).

Resignação, dissimulação, transtorno? Toda essa discussão acerca do problema da apresentação do discurso em literatura já era, na década de 40 do século passado, considerada repetitiva, reprisada, porém não esgotada. Friedman afirma que "a distinção entre contar/ mostrar - em que "tell"/"dizer" aponta para o polo "onisciência" e "show"/"mostrar" aponta para o polo da "objetividade" -encontra-se estabelecida como um lugar-comum da crítica de ficção" (FRIEDMAN, 2002, p. 172).

Chiappini (2002) vai além, afirmando que "se narrar é coisa muito antiga, refletir sobre o ato de narrar também o é" e, na antiguidade clássica, a questão já estava carregada de valor em $A$ república e na Poética9(LEITE, 2002, p. 6-7).

Se nos estudos literários ainda há panos para as mangas no debate que envolve os efeitos de sentido de cada tipo de discurso, o campo da ficção audiovisual parece ter potencializado a complexidade do assunto. Pensemos metonimicamente o caso do capítulo I do livro
Dom Casmurro, intitulado I - Do título frente ao capitulo inicial de Capitu (sem titulo).

No livro, o capitulo inicia:

Uma noite destas, vindo da cidade para o Engenho Novo, encontrei no trem da Central um rapaz aqui do bairro, que eu conheço de vista e de chapéu. Cumprimentou-me, sentou-se ao pé de mim, falou da lua e dos ministros, e acabou recitando-me versos. A viagem era curta, e os versos pode ser que não fossem inteiramente maus. Sucedeu, porém, que como eu estava cansado, fechei os olhos três ou quatro vezes: tanto bastou para que ele interrompesse a leitura e metesse os versos no bolso.

- Continue, disse eu acordando.

- Já acabei, murmurou ele.

- São muito bonitos (ASSIS, 2000, p. 13).

9 Na nomenclatura de Todorov (1980), a distinção entre "tell" e "show" pertence aos "modos" da narração e não aos "aspectos". Os "modos" concernem à maneira pela qual o narrador expõe a história, enquanto os "aspectos" à maneira pela qual a história é percebida pelo narrador. O "dizer" está relacionado à narração e o "mostrar" à representação. 


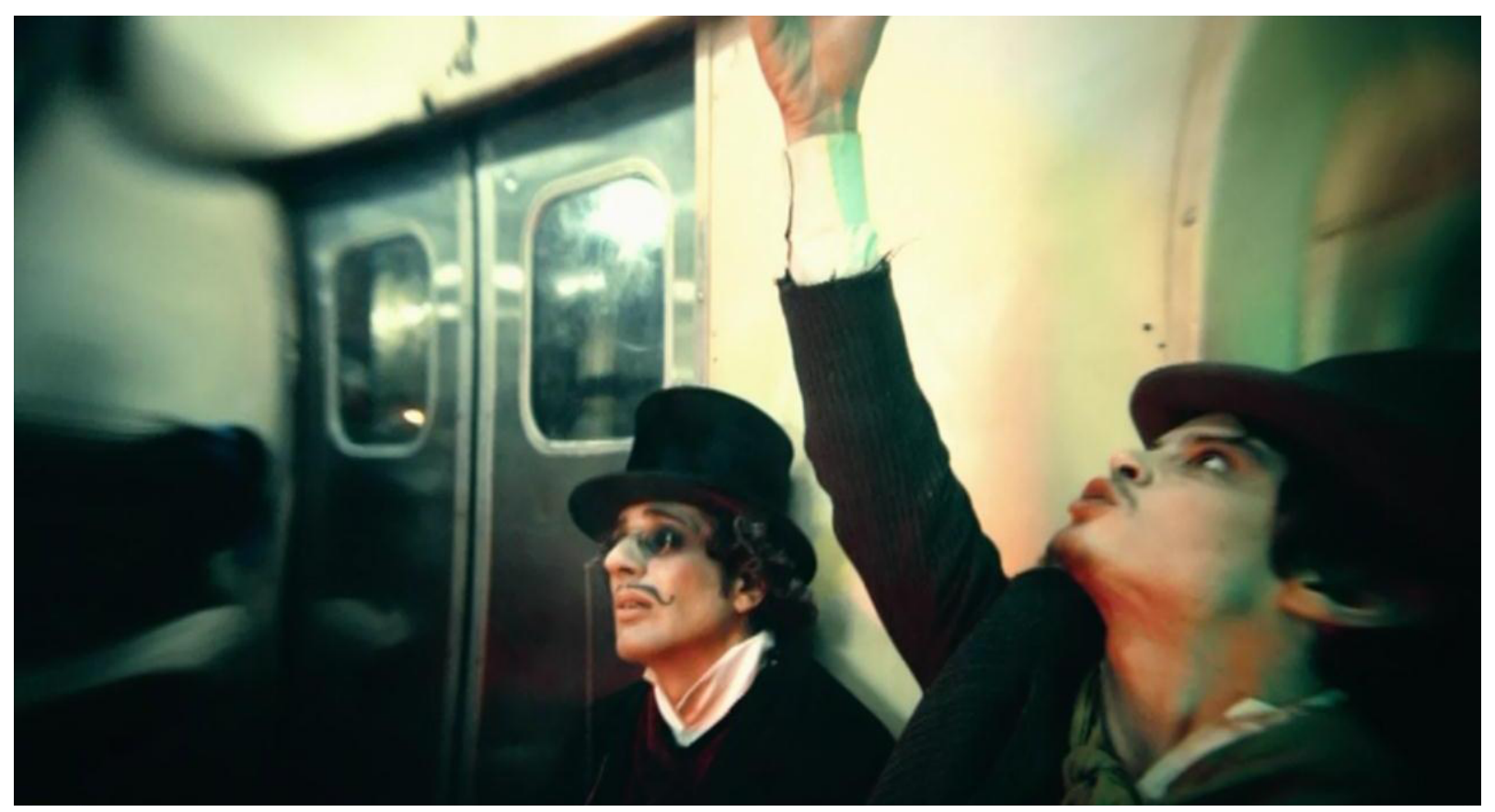

Imagem 3 - O "Poeta do trem" recita versos enquanto o agora "Dom Casmurro" cochila (CARVALHO, 2009).

Esse fragmento nos serve de amostra para confrontar diversas concepções narrativas sobre os tipos de discurso na ficção. Aristóteles (apud LEITE, 2002) defendia a mimese (imitação, como temos trabalhado) como forma de revelação da essência do real (e aqui Ligia Chiappini não destrincha o conceito de real). Foi amparado nesse pensamento que Lubbock (1954, p. 148) concluiu que a história deveria parecer verdadeira e, para tanto, ela deveria ser mostrada - usando o discurso direto -, deveria falar por si só, e a "mera" afirmação do narrador não seria capaz de instaurar a "arte da ficção".

O ideal de verdade da ficção, então, seria algo muito próximo do drama, isso é, com menos distância entre aquilo que se fala daquilo que se fala - porém parte significativa das falas. Mas o drama são narrações. Ora, o próprio Friedman chegou a afirmar que a ficção era pra ser lida e não vista e ouvida, como o drama, que tem sua narrativa quase totalmente constituida de falas.

O drama comumente faz uso da narrativa sumária e recorreu, não raras vezes, à rubrica para ajudar o leitor na construção da verdade ficcional. Sandra Luna (UFPB, 2012) adverte que a narrativa pura - a épica - é por natureza objetiva, enquanto que o drama é subjetivo e objetivo; o romance, por seu turno, que faz uso da forma mista é, como o épico, uma narrativa dramática. Contar a história, ao contrário do que Lubbock pensava, não impede que o informador seja tão cúmplice do leitor quanto a informação.

Certamente, se fornecêssemos esse trecho de Dom Casmurro a diversos cineastas e diretores para que fosse adaptado para um meio audiovisual, depararíamo-nos com uma série de propostas de trabalho distintas. Nenhuma delas ousaria preterir toda a riqueza informativa disponibilizada na narrativa sumária sem prejuizo para a leitura do texto. A narrativa sumária, a despeito de Lubbock, é a ficção pulsando forte com a verdade que o discurso indireto possui, colocando com clareza a descrição das coisas, os sentimentos das personagens, os estados mentais, etc.

Observemos o trecho transformado em imagem (Imagem 3). Como poderiamos supor com o necessário laconismo e precisão que aquela era uma noite qualquer, qual era o destino do trem, que a viagem era curta, a origem do rapaz, o que nele era familiar, como se deu o encontro dos moços, como se postaram, de que falaram, como se entretiveram, o que um achou 
dos versos, qual era a disposição fisica de um deles, como um reagiu ao recital e como o outro se portou diante de tal reação?

A solução encontrada por Luiz Fernando Carvalho para que os detalhes - muito significativos - espalhados por todo o livro não fossem desperdiçados foi manter o narradorpersonagem e suas falas, tal qual no romance E, dessa forma, sem que sua presença ostensiva interrompesse o fluxo da narrativa, comprometesse a ilusão da realidade ou criasse obstáculo entre ela e o leitor, como Friedman (2002) propõe acerca da ficção literária.

A pergunta que se interpõe é dificil de administrar: a estranha figura do narrador de Luiz Fernando Carvalho não causa perda de sedução retórica em relação ao polido e contido narrador do livro? Ao menos, na maior parte do romance, ele consegue transparecer tal polidez e contenção.

Os supostos problemas de interrupção do fluxo da narrativa, quebra da ilusão de realidade e falha na comunicação com o leitor/espectador podem quedar como obstáculos ou como soluções, procedimentos encontrados para a construção da metaficcionalidade e da hipertextualidade, como em Capitu e em Dom Casmurro.

Para Platão, que aqui citamos indiretamente apenas para destacar as diversas leituras feitas a respeito de suas teses, o ideal, sobretudo no discurso longo, seria equilibrar imitação e narração, como acontece de fato no romance ocidental (apud LEITE, 2002, p. 6-7). Em Capitu, ao longo dos oitenta e seis capitulos da microssérie, em apenas seis, o narrador Dom Casmurro não aparece nem fala (Prima Justina, No passeio público, A alma é cheia de mistérios, A missa, Depois da missa e Capitu que entra) e a narração fica por conta do narrador-câmera. $O$ que predomina na narrativa é uma coadunação equilibrada da atitude patente do narrador com o próprio evento, alternando trechos de econômico sumário com outros com detalhes vividos dos acontecimentos, enfatizando, a um tempo, a cena e a própria narração (FRIEDMAN, 2002, p. 173).

Além disso, o diretor da microssérie soube usufruir do dilema acerca do discurso indireto da literatura que, por vezes, se torna, digamos, direto-indireto quando adaptado para um meio audiovisual. Quando o autor refere o acontecimento usando a sentença "Cumprimentou-me, sentouse ao pé de mim, falou da lua e dos ministros, e acabou recitando-me versos" (ASSIS, 2000, p. 13), esse enunciado adquire sentido diretivo e cênico a partir do momento em que se torna imagem, pois a referência ao evento passa a ser imagética, direta.

A narração "narra e ostenta". Ao assistir o trecho da imagem anterior (Imagem 3) notamos algo como uma redundância discursiva, onde coexistem o texto verbal (por vezes, em Capitu, aparecendo escrito e falado) e o visual, ratificando-o.

Outro aspecto de grande utilidade a este estudo é o da perspectiva, situada também como subcategoria contida dentro do modo. Para desenvolver o estudo da perspectiva, Genette (1979) recorre a outro teórico que se aprofundara na questão da posição do narrador e no seu ponto de vista sem, contudo, atribuir-lhe essa nomenclatura.

Norman Friedman, em seu O ponto de vista na ficção (2002), expande e problematiza as conclusões a que chegaram Cleanth Brooks e Robert Penn Warren (1943), ao, de maneira bastante elementar, posicionarem o narrador, no que concerne ao ponto de vista, como observador externo ou, no tangente ao seu caráter, como presente ou ausente da ação.

A tipologia de Brooks e Warren é "sucinta" - na eufêmica acepção de Maria Lúcia Dal Farra (1978) -, não dá conta da variedade de facetas possiveis do narrador. Lubbock (1954, p. 157) aprofundou o olhar sobre o narrador e acrescentou que sua posição é um meio para uma apresentação coerente e vivida da história e Schorer (apud FRIEDMAN) ressaltou que os usos do ponto de vista servem tanto como modo de delimitação dramática como de definição temática.

Outros teóricos, como Pouillon (1974) e Todorov (1971), também têm uma tipologia diferente. Porém, as divergências em relação ao pensamento de Friedman se resumem à nomenclatura, enquanto os conceitos são equivalentes. Maria Lúcia Dal Farra (1978) fala em "correspondência" e "mesmas acepções" e inclui 
Boris Tomachevski entre esses narratologistas, sendo os termos "narração subjetiva" e "narração objetiva" ambos cunhados pelo teórico.

Os tipos de narrador/narração de Pouillon (1974, p. 114) denominam termos como visão por trás, visão com, visão de fora e os de Todorov (1971, p. 238-240), como narrador>personagem, narrador $=$ personagem e narrador $<$ personagem podem ser abarcados pela teoria de Friedman. Ao final, os conceitos de visão, campo ou ponto de vista estão tecnicamente incluidos no que Genette, agora na esteira de Brooks e Warren, chama de focalização.

O trunfo de Pouillon reside no seu esforço em tentar fornecer uma conceituação para um tipo de narrador que é o mesmo de Dom Casmurro, o de primeira pessoa ou "ensimesmado", como usa Dal Farra (1978). Pouillon, em Tempo e novela, afirma que tal narrador é dotado de uma compreensão simpática e sentimental da realidade, frequentemente deformante e fonte de mal-entendido (POUILLON, 1974, p. 164).

Tzvetan Todorov, em As categorias da narrativa literária (1971), retoma a causa de Pouillon, com seus próprios termos novamente. Para ele, dois tipos de narração alicerçam a discussão: a do romance em terceira pessoa, "que não representa seu próprio processo de enunciação" e a do romance em primeira pessoa, em que "o narrador é representado", sendo "sujeito da enunciação e ao mesmo tempo do enunciado".

A "polêmica" (para usar a expressão do subtítulo do estudo de Dal Farra) em torno da narração se torna drástica quando Wayne Booth, em A retórica da ficção e Distância e ponto de vista, considera como "irrelevante" a categoria pessoa por causa das "infinitas possibilidades de conjugação dos pontos de vista" (p. 64). O discurso poderia "dilatar sua dimensão na simultaneidade de dois pontos de vista". Por trás de qualquer narrador haveria um autorimplicito mediando qualquer situação e o romance, independentemente da situação, traria sempre a figura do narrador como uma consciência focal.

Finalmente, Silviano Santiago (2002), em O narrador pós-moderno, reelabora a discussão acerca da conceituação dos narradores, trazendo uma fala pautada na evolução dos modos de narrar. Santiago argumenta que a fala em primeira pessoa, operada pelo "narrador clássico", é o modelo em que a ação é uma experiência que se tem dela. É isso que empresta autenticidade à matéria que é narrada e ao relato. No discurso em terceira pessoa não se pode falar em autenticidade da experiência e do relato porque a informação é obtida da observação de um terceiro, isso implica um rechaço e um distanciamento do narrador clássico. O auge desse movimento de afastamento produziu o narrador pós-moderno.

Para Walter Benjamim (apud SANTIAGO, 2002, p.39), entre esses, se produziu outro narrador, o narrador do romance, distante do narrador clássico por causa da negação ao "senso prático e doutrinário" e por sua função, que seria a de não mais falar de maneira exemplar a seu leitor, moral e esteticamente. E, distante do narrador pós-moderno, que narra por narrar, sem interesse pela experiência que "se subtrai da ação narrada [...] e cria um espaço para a ficção dramatizar a experiência de alguém desprovido de palavra, o narrador que se identifica com um segundo observador - o leitor." (SANTIAGO, 2002, p. 38-48).

No ensaio "Sobre alguns temas em Baudelaire", Walter Benjamin observa como a informação se posta rigidamente distante da experiência, pois não entra na tradição. Ao contrário, floresce num momento de atrofia da experiência, quando "nenhum leitor tem mais facilmente qualquer coisa para poder contar ao outro" (BENJAMIN, 1980b, p. 31). Na imprensa, há o momento de exclusão do acontecimento do contexto "em que poderia afetar a experiência do leitor". O que inevitavelmente seria feito, tendo em vista os ditames da informação, com suas exigências de novidade, brevidade, etc., bem como os da diagramação, que expõe os assuntos de maneira fragmentária e sem relação entre si nas páginas publicadas.

Já em "O narrador" (BENJAMIN, 1980a), o filósofo alemão analisa um contexto de perda da experiência, com o rareamento da narrativa oral, tendo caído de cotação socialmente a experiência que anda de boca em boca. Para Benjamin, o advento do romance já acenaria, como exemplo 
remoto, para as forças históricas seculares que teriam afastado a narrativa do "âmbito do discurso vivo". Estaria no romance um sinal de decadência da experiência, com o romancista sendo um ser segregado, desorientado, que não sabe aconselhar - um sujeito roubado pela experiência.

Para Benjamin, porém, a informação, como nova forma de comunicação surgida no capitalismo avançado, ameaçaria a narrativa bem mais que o romance. Exigindo plausibilidade e verificabilidade, ela, em todas as suas frentes, tolheria a germinação de significações.

Cada manhã nos informa sobre as novidades do universo. No entanto somos pobres em história notáveis. Isso ocorre porque não chega até nós nenhum fato que já não tenha sido impregnado de explicações. Em outras palavras: quase mais nada do que acontece beneficia a narrativa, tudo reverte em proveito da informação. Com efeito, já é metade da arte de narrar, liberar uma história de explicações à medida que ela é reproduzida (BENJAMIN, 1980a, p. 61).

Assim, faltaria à informação certa amplitude de oscilação presente na narrativa. Dessa forma, se mantém viva apenas no instante em que é nova, "vive apenas nesse instante, precisa entregarse inteiramente a ele" (BENJAMIN, 1980a, p. 62). Ao contrário, a narrativa não se exaure, traz possibilidades de desdobramentos futuros.

Benjamin fornece como exemplo a narrativa de Heródoto, que trata da prisão por Cambises, rei persa, de Psanemita, rei egípcio. Após vitória em guerra, Cambises obrigou Psanemita a assistir ao desfile do triunfo persa, a ver sua filha servindo como escrava aos persas e seu filho ser levado à execução. O rei não esboçou reação a todas essas cenas atordoantes, no entanto, ao reconhecer "um de seus criados, homem velho e empobrecido, nas filas dos prisioneiros, bateu com os punhos na cabeça e deu todos os sinais da dor mais profunda" (BENJAMIN, 1980a, p. 61).

Pensando sobre a interpretação que Montaigne faz dessa narrativa, o ensaísta alemão especula sobre outras e, principalmente, ressalta o impacto em espanto e reflexão que ela conserva através dos tempos - um poder que se assemelha ao dos "grãos de semente que, durante milênios hermeticamente fechados nas câmaras das pirâmides, conservaram até hoje sua força de germinação" (BENJAMIN, 1980a, p. 62).

Em O narrador pós-moderno, Silviano Santiago aponta os três estágios da história do narrador sistematizados por Benjamin (por volta de 1935) justamente no texto "O narrador". O primeiro seria o do narrador clássico, que teria por função "dar ao seu ouvinte a oportunidade de um intercâmbio de experiência (único valorizado no ensaio)". O segundo se configuraria com o do narrador do romance, "cuja função passou a ser de não mais poder falar de maneira exemplar ao seu leitor" (e aqui lembramo-nos da observação de Benjamin de que o romancista está desorientado e não sabe aconselhar). No terceiro momento, o narrador, "que é jornalista", só "transmite pelo narrar a informação, visto que escreva não para narrar a ação da própria experiência, mas a que aconteceu com x ou y" (SANTIAGO, 1989, p. 39).

No primeiro caso, o narrador expõe uma vivência, a experiência de uma ação. Nos dois seguintes, ele passa "uma informação sobre outra pessoa", tem a "experiência proporcionada por um olhar lançado" (SANTIAGO, 1989, p. 38). Ainda: no primeiro caso (narrador clássico) "a coisa é mergulhada na vida do narrador e dali retirada". No romance, "a coisa narrada é vista com objetividade pelo narrador, embora este confesse tê-la extraído de sua vivência". No terceiro momento, "a coisa narrada existe como puro em si, ela é informação, exterior à vida do narrador" (SANTIAGO, 1989, p. 40). Para Santiago, o narrador pós-moderno é o que transmite

[...] uma 'sabedoria' que é decorrência da observação de uma vivência alheia a ele, visto que a ação que narra não foi tecida na substância viva da sua existência. Nesse sentido, ele é o puro ficcionista, pois tem de dar 'autenticidade' a uma ação que, por não ter o respaldo da vivência, estaria desprovida de autenticidade. Esta advém da verossimilhança que é produto da lógica interna do relato. O narrador pós-moderno sabe que o 'real' e o 'autêntico' são construções de linguagem (SANTIAGO, 1989, p. 40). 
Santiago observou as tensões entre o jornalismo e a literatura percebendo como, no primado da informação, a figura do narrador passa a ser a de "quem se interessa pelo outro (não por si) e se afirma pelo olhar lançado ao seu redor, acompanhando seres, fatos e incidentes (e não por um olhar [...] que cata experiências vividas no passado)". Dessa maneira, assinala que "pode-se falar que o narrador olha o outro para levá-lo a falar (entrevista), já que ali não está para falar das ações de sua experiência" (SANTIAGO, 1989, p. 43).

Finalizando, percebemos como Genette (1979), fez o termo focalização sobressair e tornar-se o mais recorrente nos estudos narratológicos. Segundo ele, visão, campo ou ponto de vista é preferivel por ser mais abstrato, mas isso provavelmente ocorreu por ter notado que o narrador nunca analisa objetivamente os pensamentos e as percepções da personagem focal e que "a distinção entre os diferentes pontos de vista nem sempre é tão nítida quanto a simples consideração dos tipos puros poderia fazer supor" (GENETTE, 1979, p.190). A consideração dessa teoria arrasa a tentativa de Dom Casmurro de se posicionar como sujeito (narrador) potencialmente distante ou objetivo em relação ao que diz. Já que, como sustentou Pouillon, sua visão da realidade é sentimental, deformante e fonte de mal-entendido, além de ser desinteressada de compromissos estéticos e morais para com o leitor, como afirmou Santiago (2002).

\section{REFERÊNCIAS}

ALEXANDRE JR., Manuel. Introdução. In: ARISTÓTELES. Retórica. Trad. Manuel Alexandre Júnior. Paulo Farmhouse Alberto e Abel do Nascimento Pena. 3. ed. Lisboa: Imprensa Nacional - Casa da Moeda, 2006. (Coleção Biblioteca de Autores Clássicos.)

ALLEN, Woody. Noivo neurótico, noiva nervosa. [Filme]. EUA. 1977. 35mm. $93 \mathrm{~min}$.

ALMEIDA, Carlos Heli de. Luiz Fernando Carvatho: 'não corro atrás de elogios'. Jornal do Brasil. dez./2008.

ARISTÓTELES. Retórica. Trad. Manuel Alexandre Júnior, Paulo Farmhouse Alberto e Abel do Nascimento Pena. 3. ed. Lisboa: Imprensa Nacional - Casa da Moeda, 2006. (Coleção Biblioteca de Autores Clássicos.)
ARRAES, Guel. O Auto da Compadecida. IMicrossérie]. 2000.

ASSIS, Cláudio. Baixio das bestas. [Filme]. Brasil. 2007. $80 \mathrm{~min}$.

ASSIS, Machado de. Dom Casmurro. São Paulo: Ed Ática, 2000.

AUMONT, Jacques. Moderne? Paris : Ed. Cahiers du Cinéma, 2007

AZERÊDO, Genilda. Jane Austen, Adaptação e Ironia: Leitura Introdutória de Emma. Graphos, João Pessoa, n.1, v. 4, 1999

AZERÊDO, Genilda. O discurso ficcional na TV: sedução e sonhos em doses homeopáticas. São Paulo: Editora da USP, 2002

BAZIN, André. O cinema da crueldade. São Paulo: Martin Fontes, 1989

BAZIN, André. Por um cinema impuro. In: O cinema: ensaios. São Paulo: Braziliense, 1991. p. 82-104.

BENJAMIN, Walter. O narrador. In: BENJAMIN, Walter et al. (org.). Sobre arte, técnica, linguagem e politica. Lisboa: Relógio D'água Editores, 1992. p. 27-57

BENJAMIN, Walter et al. O narrador. In: BENJAMIN Walter et al. (org.). Textos escolhidos/Benjamin, Horkheimer, Adorno, Habermas. São Paulo: Abril, 1980

BRITO, João Batista de. Narrativas em conflito: três questões diferentes sobre a diferença entre literatura e cinema. In: Literatura no cinema. São Paulo: Unimarco, 2006

BRITO, João Batista de. Dois modelos de cinema. In Imagens amadas. São Paulo: Ateliê, 1995.

BULHÕES, Marcelo. Para além da "fidelidade" na adaptação audiovisual: o caso da minissérie televisiva Capitu. Revista Galáxia, São Paulo, n. 23. p. 59-71, jun. 2012.

CALDWELL, Helen. O Otelo Brasileiro de Machado de Assis. Rio de Janeiro: Ateliê Editorial, 2002.

CAMPEDELLI, Samira Youssef. A telenovela. São Paulo: Ática, 2001.

CÁNEPA, Laura Loguercio. Expressionismo alemão. In: MASCARELLO. Fernando (org.). História do cinema mundial. Campinas: Papirus, 2006.

CARVALHO, Luiz Fernando. A Pedra do Reino. [Microssérie]. Rio de Janeiro, 2007.

CARVALHO, Luiz Fernando. Afinal, o que querem as mulheres? [Microssérie]. Rio de Janeiro, 2010.

CARVALHO, Luiz Fernando. Capitu. [Microssérie]. Rio de Janeiro, 2009

CARVALHO, Luiz Fernando. Hoje é dia de Maria. [Microssérie] 2005

CHALHUB, Samira. A metalinguagem. São Paulo: Editora Ática, 1998 
COLOMBO, Sylvia. Hoje é dia de Capitu. Folha de São Paulo. Disponivel em: http://www1.folha.uol.com.br/ fsp/ilustrad/fq2211200807.htm. Acesso em: 9 dez. 2008

DAL FARRA, Maria Lúcia. O narrador ensimesmado: o foco narrativo em Virgílio Ferreira. São Paulo: Ática, 1978.

FREUD, Sigmund. O estranho, 1919. In: História de uma neurose infantil. Rio de Janeiro: Imago, 1996. p. 233-270. (Edição Standard Brasileira das Obras Psicológicas Completas de Sigmund Freud, 17).

FRIEDMAN, Norman. O ponto de vista na ficção: o desenvolvimento de um conceito crítico. Trad.: Fábio Fonseca de Melo. Revista USP, São Paulo, n. 53, p. 166-182, mar./maio, 2002.

FURTADO, Jorge. O homem que copiava. [Filme]. Porto Alegre. 2003. $123 \mathrm{~min}$.

GENETTE, Gérard. Discurso da narrativa - ensaio de método. Trad.: Fernando Cabral Martins. Lisboa: Arcádia, 1979.

GENETTE, Gérard. Palimpsestos: a literatura de segunda mão. Trad.: Luciene Guimarães e Maria Antônia Ramos. Belo Horizonte: FALE/UFMG, 2006. 7-48.

GLEDSON, John. Machado de Assis: impostura e realismo: uma reinterpretação de Dom Casmurro. Trad:: Fernando Py. São Paulo: Companhia das Letras, 1991.

Globo, O. Divulgação. 07/12/2008. Disponivel em: http://oglobo.globo.com/blogs/prosa/posts/2008/12/09/a-capitu-de-luiz-fernando-carvalho-145085.asp. Acesso em: 11 jan. 2013.

GÓES, Moacyr. Dom. [Filme]. Brasil. 2003. 91 min.

GOMES, Livia Cristina. A peste da mimesis. Revista USP, São Paulo, n. 77, mar./maio 2008.

GOMES, Paulo Emílio Salles. A personagem cinematográfica. In: CANDIDO, Antonio et alii. A personagem de ficção. São Paulo: Perspectiva, 2009.

HUTCHEON, Linda. Uma teoria da adaptação. Trad.: André Chechinel. Florianópolis: Editora da UFSC, 2011.

JAKOBSON, Roman. A decadência do cinema? Trad: Francisco Achcar. In: Linguística. Poética. Cinema. São Paulo: Perspectiva, 1970

JAKOBSON, Roman. Linguistica e Comunicação. São Paulo: Cultrix, s.d.

JOST, François. Seis lições sobre televisão. Porto Alegre: Editora Sulina, 2004

KRISTEVA, Julia. Introdução à semanálise. Trad.: Lúcia Helena França Ferraz. São Paulo: Perspectiva, 1974

KRISTEVA, Júlia. Le mot, le dialogue, le roman. In: Semiotike. Recherche pour une sémanalyse. Paris: Seuil, 1969 .

LEITE, Ligia Chiappini Moraes. O foco narrativo lou A polêmica em torno da ilusão). São Paulo: Ática, 2002;

LUBBOCK, Percy. A técnica da ficção. Trad.: Octávio Mendes Carvalhos. São Paulo: Cultrix, 1954.
MAGGIO, Sérgio. Luiz Fernando Carvalho lança sua visão estética sobre o romance Dom Casmurro. Correio Braziliense. 09/12/2008. Busca realizada às 23h32 de 9/1/2013 em: http://divirta-se.correioweb. com.br/materias.htm?materia $=5497$.

MARTIN, Marcel. A linguagem cinematográfica. Trad.: Paulo Neves. São Paulo: Brasiliense, 2003.

MERQUIOR, José Guilherme. Machado de Assis e a prosa impressionista. In: De Anchieta a Euclides: breve história da literatura brasileira. Rio de Janeiro, 1977.

MOUSINHO, Luiz Antônio. O telespectador deslocado: o programa Cena Aberta e o seriado Cidade dos Homens. In: PAIVA, Cláudio Cardoso de et al. Midias e culturalidades: análises de produtos, fazeres e interações. João Pessoa: Editora Universitária da UFPB, 2007. p. 115-140.

POUILLON, Jean. O tempo no romance. São Paulo: Cultrix/EDUSP, 1974.

PUCCI JR., Renato Luiz. A microssérie Capitu: adaptação televisiva e antecedentes filmicos. In: XX ENCONTRO DA ASSOCIAÇÃO NACIONAL DOS PROGRAMAS DE PÓS-GRADUAÇÃO EM COMUNICAÇÃO, 2011, Porto Alegre.

PUCCI JR., Renato Luiz. Cinema moderno e de vanguarda na TV: o paradoxo pós-moderno de Cena Aberta. In: HAMBURGUER, Esther et al. Estudos Socine de Cinema: ano IX. São Paulo: Annablume, Socine, 2008. p. 325-232.

PUCCI JR., Renato Luiz. Intersecção pós-moderna entre cinema e TV: o caso de O Auto da Compadecida. In: CATANI, Afrânio Mendes et al. Estudos Socine de cinema: ano VI. São Paulo: Nojosa Edições, 2005. p. 325-332.

PUCCI JR., Renato Luiz. Particularidades narrativas da microssérie Capitu. In: BORGES, Gabriela; PUCCI JR., Renato; SELIGMAN, Flávia (org.). Televisão: formas audiovisuais de ficção e de documentário. São Paulo: Faro e São Paulo, 2011. Vol. I.

REIS, Carlos; LOPES, Ana Cristina M. Dicionário de Teoria da Narrativa. São Paulo: Editora Ática, 1988.

SANTIAGO, Silviano. Retórica da verossimilhança. In: Uma literatura nos trópicos. São Paulo: Perspectiva, 1978.

SANTIAGO, Silviano. O narrador pós-moderno. In: Nas malhas da letra: ensaios. Rio de Janeiro: Rocco, 2002. p. 38-60.

SANTIAGO, Silviano. O narrador pós-moderno. In: SANTIAGO, Silviano. Nas malhas da letra. São Paulo: Companhia das Letras, 1989.

SARACENI, Paulo César. Capitu. [Filme]. Brasil. 1968. $105 \mathrm{~min}$.

SCHWARZ, Roberto. A poesia envenenada de Dom Casmurro. In: Duas meninas. São Paulo: Companhia das Letras, 1997.

STAM, Robert. A literatura através do cinema: realismo, magia e a arte da adaptação. Trad.: Heloísa Jahn. Belo Horizonte: Editora UFMG, 2008. 
STAM, Robert. Teoria e prática da adaptação: da fidelidade à intertextualidade. In: CORSEUIL, Anelise Reich (ed.). Ilha do desterro: Film Beyound Boundaries, Florianópolis, UFSC, n. 51, p. 19-53, jul./dez. 2006.

TODOROV, Tzvetan et al. As categorias da narrativa literária. Trad.: Eni Orlandi. In: Análise estrutural da narrativa. Petrópoles: Editora Vozes Ltda, 1971.

VISCONTI, Luchino. Morte em Veneza. [Filme]. Itália. 1971. $130 \mathrm{~min}$.

\section{Endereço para correspondência:}

Alexandre de Assis Monteiro

Av. João da Mata, 256 - Jaguaribe, João Pessoa - PB, 58015-020

Campus I - Lot. Cidade Universitaria, PB, 58051-900 